DOI:

\title{
ГОРМОНИ СЕРЦЯ: БІОМЕДИЧНІ ДОСЛІДЖЕННЯ ДИСТАНТНИХ, ПАРАКРИННИХ І АУТОКРИННИХ ВЗАЄМОДІЙ
}

\author{
О. П. Мінцер, В. М. Заліський, М. Ю. Болгов ${ }^{1}$ \\ Національна медична академія післядипломної освіти імені П. Л. Шупика \\ ${ }^{1}$ ДУ «Інститут ендокринології та обміну речовин ім. В. П. Комісаренка НАМН України»
}

\begin{abstract}
Серце відіграє центральну роль у системі кровообігу та забезпечує перенесення необхідних організму кисню, поживних речовин і білкових фракторів росту. Однак серце синтезує та продукує сигнальні молекули для зв'язку з віддаленими органами-мішенями. Вивчення давно відомих і недавно відкритих гормонів серця просуває даний механізм їхньої дії у координації з фрунцією серця та біологією органів-мішеней. Розглянуто біохімію, сигналізацію, фрункцію, регуляцію та клінічне значення репрезентативних гормонів серцевого походження 3 акцентом на їхню участь у розвитку комплексних біомедичних процесів у нормі та при серцево-судинній патології. Зроблено висновки, що обґрунтування парадигми «ендокринного серця» забезпечило перехід від класичного уявлення про серце як органа, фрункціонуючого виключно як кров'яний насос, до серця як саморегулюючої системи щодо навантаження в гуморальному плані. Вивчення гормонів серцевого походження дозволило виявити їхні загальні фрункціональні особливості та підкреслити наявність гормонозалежного механізму, що серце використовує для зв'язку з іншими органами-мішенями, які контролюють серцево-судинну функцію.
\end{abstract}

Ключові слова: гормони серцевого походження, активіновий рецептор (ActR), передсердний натрійуретичний пептид, мозковий натрійуретичний пептид С-типу, фактор росту фрібробластів, диференціювальний фрактор росту IS, фролістатин, трансформуючий фрактор росту, супресор пухлинного росту-2 (ST-2), міостатин.

\section{HEART-DERIVED HORMONES: BIOMEDICAL INTERACTION OF DISTANT, PARACRINE AND AUTOCRINE ACTION}

\author{
O. P. Mintser, V. M. Zaliskyi, M. Yu. Bolgov ${ }^{1}$ \\ Shupyk National Medical Academy of Postgraduate Education \\ ${ }^{1}$ The State Institution «V. P. Komisarenko Institute of Endocrinology and Metabolism»
}

\begin{abstract}
Background. The heart plays a central role in the circulatory system and provides the body with the necessary oxygen, nutrients and protein growth factors. However, today it can synthesize and make signaling molecules for communication with distant target organs. The study of long-known and recently discovered heart hormones promotes this mechanism of their action in coordination with the function of the heart and the biology of target organs. The purpose of the study was to conceptualization of the «endocrine heart» paradigm.

Materials and methods. Results. The paper considers the biochemistry, signaling, function, regulation and clinical significance of representative hormones of cardiac origin with an emphasis on their participation in the development of complex biomedical processes in normal and cardiovascular pathology. The substantiation of the «endocrine heart» paradigm provided a transition from the classical notion of the heart as an organ functioning exclusively as a blood pump to a self-regulating system in the sense of loading in the humoral plan. The study of hormones of cardiac origin revealed their common functional features and emphasize the presence of a hormone-dependent mechanism that the heart uses to communicate with other target organs that control cardiovascular function.

Conclusions. It is emphasized that regardless of the main place of hormones production (heart, other organs), the above-mentioned polypeptide hormones function synergistically, together contribute to the regulation of cardiovascular hemodynamic, affecting vascular tone, autonomic nervous system and normal heart rate and pathology.
\end{abstract}

Key words: heart-derived hormones, activin receptor (ActR), atrial natriuretic peptide, brain natriuretic peptide, C-type natriuretic peptide, fibroblast growth factor, follistatin, transforming growth factor, suppression of tumorogenosis (ST-2), myostatin. 


\title{
ГОРМОНЫ СЕРДЦА: БИОМЕДИЦИНСКИЕ ИССЛЕДОВАНИЯ ДИСТАНТНЫХ, ПАРАКРИННЫХ И АУТОКРИННЫХ ВЗАИМОДЕЙСТВИЙ
}

\begin{abstract}
О. П. Минцер, В. Н. Залесский, М. Ю. Болгов ${ }^{1}$
Национальная медицинская академия последипломного образования имени П. Л. Шупика

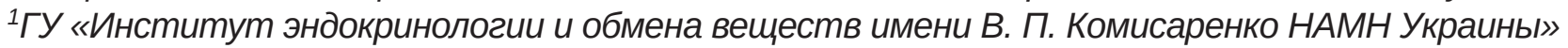

Сердце играет центральную роль в системе кровообращения и обеспечивает перенос необходимых организму кислорода, питательных веществ и белковых фракторов роста. Однако сердце может синтезировать и продуцировать сигнальные молекулы для связи с удаленными органами-мишенями. Изучение давно известных и недавно открытых гормонов сердца продвигает данный механизм их действия в координации с функцией сердца и биологией органов-мишеней. Рассмотрены биохимия, сигнализация, фрункция, регуляция и клиническое значение репрезентативных гормонов сердечного происхождения с акцентом на их участие в развитии комплексных биомедицинских процессов в норме и при сердечно-сосудистой патологии. Обоснование парадигмы «эндокринного сердца» обеспечило переход от классического представления о сердце как органа, фрункционирующего исключительно в качестве кровяного насоса, до сердца как саморегулирующейся системы касательно нагрузки в гуморальном плане. Изучение гормонов сердечного происхождения позволило выявить их общие фрункциональные особенности и подчеркнуть наличие гормонозависимого механизма, который сердце использует для связи с другими органами-мишенями, контролирующими сердечно-сосудистую функцию.
\end{abstract}

Ключевые слова: гормоны сердечного происхождения, активиновый рецептор (ActR), предсердный натрийуретический пептид, мозговой натрийуретический пептид С-типа, фрактор роста фрибробластов, дифореренцировочный фрактор роста IS, фоллистатин, трансорормирующий фрактор роста, супрессор опухолевого роста-2 (ST-2), миостатин. 
Вступ. Раніше [37] та зовсім нещодавно вийшли детальні огляди [72] про концепцію «серце як ендокринний орган». Наш аналітичний огляд до певної міри повторює основні їх положення з тією різницею, що накопичені факти розглядаються 3 онтологічних позицій.

Передсердні кардіоміоцити в серці ссавців мають фенотип частково такий, як ендокринні клітини. Дослідження, проведені у період між 1971 та 1983 роками, охарактеризували поліпептид, що отримав завдяки своїм натрійуретичним властивостям назву «передсердний натрійуретичний фактор» (atrial natriuretic factor, ANF). Інший поліпептид натрійуретичний пептид мозку (brain natriuretic peptide, BNP), виділений із головного мозку в 1988 році, згодом був охарактеризований як другий гормон, що продукується передсердями ссавців. Ці пептиди були пов’язані з підтриманням об’єму позаклітинної рідини та артеріального тиску. Більш пізні роботи продемонстрували безліч інших властивостей для ANF та BNP, що тепер називаються серцевими натрійуретичними пептидами. На додаток до серцевих натрійуретичних пептидів, у серці експресуються й інші поліпептидні гормони, що, ймовірно, діють на міокард паракринним або аутокринним способом. До них належать натрійуретичний пептид С-типу, адреномедулін, проадреномедулін N-кінцевий пептид та ендотелін-1. Експресія та секреція ANF та BNP збільшуються при різних серцево-судинних патологіях, а їхній рівень у крові використовується для діагностики та прогнозування серцево-судинних захворювань. До того ж було виявлено терапевтичне використання цих пептидів або споріднених речовин.

Мета роботи: концептуалізація парадигми «ендокринна кардіологія».

Результати та їх обговорення. Серцева діяльність необхідна для перекачування крові, що несе кисень і поживні речовини до кожної клітини організму. Відповідно серце потребує зворотного зв'язку про функціональний стан інших частин тіла для корекції та координації потреб у поживних речовинах, кисні та функціональних реакціях організму $[1,56]$.

Такі сигнали серця можуть мати різні форми i бути як нейрональними, так і ендокринними за своєю природою. Нейрональні сигнали зазвичай швидкодіючі, тоді як ендокринні сигнали можуть стимулювати зміни, що тривало перебігають. Серце може сигналізувати про свій функціональний стан до головного мозку через сенсорні нерви; мозок потім інтегрує та передає цю інформацію до інших органів і тканин. До того ж серце може виділяти сигнальні молекули в кровотік. Молекули потім переміщуються у віддалені органи, щоб безпосередньо впливати на їх біологію, і таким чином, функціонувати як серце-асоційовані гормони [2, 37].

До таких серце-асоційованих гормонів - кардіокінів належать білки, ліпіди, метаболіти. Більшість клітин серця зазвичай виділяють багато чинників у позаклітинний простір. Однак багато з них часто затримуються там, не входячи до системної циркуляції, або входять у циркуляцію як прості біомаркери без специфічних біологічних функцій із подальшою активацією окремих рецепторів на конкретних органах-мішенях.

Гормони серця з системними ефектами. У порівнянні з жировою тканиною, печінкою або поперечно-смугастою м'язовою тканиною, гормони серця набагато менш вивчені за рідкісним винятком. Найбільш відомими гормонами серця є передсердний натрійуретичний пептид (ANP) i мозковий натрійуретичний пептид (BNP), відкриті майже 40 років тому [15], які відіграють вирішальну роль у вазодилатації і натрійурезі. В недавніх роботах з'явилися дані щодо нових гормонів серця, таких як диференціювальний фактор росту (GDF-15) i міостатин [10, 28, 30, 51].

Ці дослідження обумовили появу нової дефініції - гормони серця або серцева ендокринологія.

Гормони серця володіють трьома важливими особливостями: 1) вони синтезуються та секретуються певними клітинами з подальшим надходженням у кров; 2) їх синтез, дозрівання, секреція та рівень циркуляції специфічно регулюються у відповідь на зміни серцевої функції; 3) вони діють через специфічні рецептори та завдяки механізмам сигналізації у конкретних віддалених органах-мішенях, а також виконують різні біологічні функції для координації при порушеннях серцевої функції (наприклад, зниження кров' яного тиску - ANP/BNP; інгібування росту — GDF-15). Тому нова дефініція «гормони серця/серцева ендокринологія» отримує швидке поширення $[37,56]$. Становить значний інтерес розгляд ролі GDF-15, міостатину та ANP/BNP у серцево-судинній системі, а також ролі факторів, що додатково секретуються серцем (із вираженою клінічною залежністю) та діють аутокринним і паракринним шляхом для регуляції регіональної функції серця.

GDF-15 є дівергентним членом сімейства трансформуючих факторів росту (TGF- $\beta$ ). Вперше 
GDF-15 був виявлений декількома незалежними групами дослідників і позначений як макрофагальний інгібуючий цітокін-1, плацентарний морфогенетичний фактор, плацентарний TGF- $\beta$ або фактор, отриманий із простати [27]. При фізіологічних умовах експресія GDF-15 низька. При серцевосудинних захворюваннях синтез і секреція GDF-15 істотно підвищуються. На додаток до того, що він $€$ корисним сироватковим біомаркером серцевосудинних захворювань, порівняно недавно було показано, що секреція GDF-15 у серці сповільнює зростання та розвиток дитячого організму, пригнічуючи сигнальний шлях гормону росту в печінці, i таким чином функціонує як гормон серцевого походження [27].

Попередником GDF-15 є молекула preproGDF-15, що має скорочену N-кінцеву сигнальну послідовність із 29 амінокислот, а також C-кінцевий глікозильований pro-GDF-15 із 279 амінокислот, що дозволяє утворювати гомодимер через міжмолекулярний дисульфідний зв'язок [69]. Три члена сімейства PCSK (proprotein convertase subtilisin/kexin) — PCSK 3 (також відомий як furin), PCSK 5 i PCSK 6 сприяють розщепленню proGDF-15 одразу після консервативної послідовності RXXR (in vitro та in vivo), створюючи зрілі форми GDF-15 димеру, що є основною циркулюючою молекулою GDF-15 [13]. Секреція GDF-15 у серці $є$ малодослідженою та залишається не з'ясованим питання: чи знаходиться GDF-15 у клітинних гранулах перед секрецією. Pro-GDF-15 виявлено в позаклітинному матриксі в пухлинних клітинах, що вказує на те, що pro-GDF-15 може секретуватися і що PCSK-медійоване дозрівання може відбуватися позаклітинно [70].

Значний прогрес у розумінні біології GDF-15 стався після недавньої ідентифікації $\alpha$-подібного рецептора GDNF-сімейства (GFRAL) як істинного рецептора GDF-15 [32, 33, 50, 66]. Ці дослідження переконливо показують, що гомодимер GDF-15 зв’язується $з$ гомодимером GFRAL, який потім рекрутується й активує рецепторну тирозинкіназу для подальшої внутрішньоклітинної сигналізації [33, 50]. До того ж, як повідомляється, GFRAL експресується тільки в певних нейтронах, розташованих в area postrema і ядрах солітарного тракту стовбура головного мозку.

Численні клінічні дослідження показали, що рівень циркулюючого GDF-15 підвищується при різних захворюваннях серця, включаючи гострий коронарний синдром і серцеву недостатність, а також служить цінним діагностичним і прогностичним біомаркером цих захворювань [71]. Рівень GDF-15 у серці регулюється на декількох етапах, включаючи синтез і оброблення (процесинг). Регуляторна мережа гена GDF-15, що індукує транскрипцію GDF-15 - білка серця, була виявлена за допомогою одноядерного РНК-секвенування (snRNA-Seq) у генетичних мишачих моделях серцево-судинних захворювань [61]. Одночасно було виявлено участь численних факторів (зокрема GATA4, анфолдинга білків) у контролі синтезу GDF-15 [34]. Недавні дослідження також показали, що GDF-15 виконує важливі серцево-судинні функції та служить біомаркером. GDF-15 проявляє захисні ефекти в мишачих моделях ішемії/реперфузійного ушкодження та гіпертрофії серцевого м'яза, викликаних перевантаженням тиском [29], ймовірно діючи аутокринним або паракринним шляхом локально (в серці).

Секреція GDF-15 за межі серцево-судинної системи сприяє ефектам пригнічення апетиту та нудоти, що практично повністю залежать від GFRAL [32, 33, 50, 66]. Відповідно, загальногеномні асоціативні дослідження виявили кілька локусів у межах гена GDF-15, кожні пов’ язані з hyperemesis gravidarum (rs16982345) [45], (rs17724992) [31], раком передміхурової залози (rs1058587) [35], ризиком розвитку гіпертрофії лівого шлуночка (rs4808793) [65], що підкреслює зв’язок клінічних даних із біологією гормону GFR-15.

Рецептор GDF-15 — GFRAL на сьогодні знаходиться під пильною увагою дослідників в аспекті двох основних терапевтичних застосувань: 1) активація GDF-15 — GFRAL використовується для лікування метаболічних порушень, включаючи ожиріння, цукровий діабет 2-го типу, жирову хворобу печінки [67]; а також 2) інгібування GDF-15 — GFRAL для лікування анорексії і ракової кахексії [67]. Клінічні дослідження за цими напрямами ще не завершені.

Міостатин є ще одним членом суперродини TGF-ß. Вiн уперше був виявлений під час скринінгу в бібліотеці білків скелетних м'язів [43] i добре себе зарекомендував при дослідженнях змін м'язової маси. Міостатин насамперед експресується в скелетних м'язах, однак низькі рівні міостатину виявлені й у серці (в фізіологічних умовах і з переважною локалізацією у волокнах Пуркіньє) [49].

Детально GDF-15 - міостатин синтезується у вигляді «prepro»-білка, що потім просувається 
шляхом глікозилювання та гомодимеризації через міжмолекулярний дисульфідний зв'язок. Після видалення N-кінцевої сигнальної послідовності залишається проміостатин, який далі протеолітичним шляхом послідовно відпрацьовується PCSK 3 і металопротеїназою - кістковим морфологічним білком 1 для повної активації [41]. Хоча проміостатин може розщеплюватися PCSK 3 всередині клітини, вважається, що його частина секретується та обробляється позаклітинно [4]. Проте залишається значною мірою невідомим, як циркулюючий міостатин видаляється або розкладається.

Рецепторами для міостатину розглядаються активовані рецептори (ActR), які є загальними для інших членів сімейства TGF- $\beta$, включаючи GDF-11 i активін-A. ActR включає два гетеромерних одиночних трансмембранних типи рецепторів серин/треонінкінази (тип I — ActR I і тип II — ActR II). ActR II безпосередньо зв’язується з міостатином, потім рекрутується і фосфорилює ActR I (до ALK4 або ALK5) у своєму цитозольному багатому гліціном/ серином домені, який, зі свого боку, фосфорилює і активує білки SMAD 2/3. Активований комплекс SMAD 2/3 далі інгібує проліферацію клітин скелетних м'язів і синтез білка завдяки кільком механізмам, що включають регуляцію експресії генів і інгібування mTOR. Міостатин зв'язується як з ActR типу IIA (ActR IIA), так і з типом IIB (ActR IIB) in vitro. Однак трансгенні миші, які експресували домінантно-негативну форму ActR IIB, імітували M'язовий фенотип мишей із дефіцитом міостатину [40], що вказує на те, що рівень ActR IIB достатній для інгібування міостатином зростання скелетних м’язів in vivo.

У серцево-судинній системі рівень міостатину як у серці, так і в кровотоці підвищується при інфаркті міокарда або серцевій недостатності [10, 48]. Активність ферменту кісткового морфогенетичного білка 1 у процессингу міостатину також була підвищена в серці у пацієнтів із ішемічною або дилатаційною кардіоміопатією [48], а також у хворих із інфарктом міокарда, що вказує на те, що міостатин є потенційним біомаркером цих патологічних подій у серці. Поряд із цим, міостатин ActR IIB сигналізація являє собою багатообіцяючу мішень для виникнення кахексії і атрофії м’язів завдяки зниженню зв'язування антиміостатинблокуючих антитіл (JA-16) з міостатин-Act RIIB у мишей із серцевою недостатністю [46].

ANP i BNP, що переважно синтезуються та секретуються у міокарді, мають добре виражену гормональну функцію, яка регулює водний і електролітний баланс усього організму [15]. Детально GDF-15 і міостатин, ANP і BNP синтезуються у вигляді препропептидів і розщеплюються протеазой Corin або PCSK 3 для вивільнення цих пептидів у зрілій і активній формі [53]. Corin, зі свого боку, активується проконвертазою PCSK 6, а така активація необхідна для підтримки нормального кров'яного тиску [52].

Найважливіші фізіологічні функції ANP і BNP обумовлені їхньою участю в регуляції гемодинаміки всього організму, опосередкованою їхніми специфічними рецепторами, що експресуються в тканинах-мішенях, включаючи нирки, надниркові залози, головний мозок і гладку мускулатуру судин [20]. У ссавців відомо три типи рецепторів до натрійуретичного пептиду: NPR-A, NPR-B i NPR-C. Процес зв'язування NPR-A i NPR-B каталізує вироблення циклічного гуанозинмонофосфату (другого месенджера), що додатково активує нижче розташовані мішені в різних тканинах [55]. На відміну від NPR-A і NPR-B, NPR-C відрізняється коротким внутрішньоклітинним доменом, що не призводить до підвищення активності гуанілатциклази і не впливає на рівень внутрішньоклітинного циклічного гуанозинмонофосфату. Отже, NPR-C функціонує як «рецептор кліренсу» за допомогою інтерналізації, а також врівноважує активність циркулюючих ANP і BNP [68].

Щодо логіки інгібіції Na-K-АТФази і функціонування передсердного натрійуретичного петиду, то в роботі [39] підкреслено, що після початкової демонстрації ендогенного інгібітора (ендогенних інгібіторів) натрієвої помпи підтверджується наявність уабаїноподібних факторів (УПФ) у плазмі крові, сечі, спинномозковій рідині та різних тканинах. Деякі з цих факторів є добре відомими ендогенними сполуками, що in vitro демонструють інгібування Na-K-АТФази, витіснення 3Н-уабаїну i перехресну реакцію з антитілом до дигоксину. Малі інгібітори натрієвої помпи, що можуть мати гіпоталамічне походження, також були виявлені в різних моделях артеріальної гіпертензії у тварин i у пацієнтів із гіпертонічною хворобою та можуть відігравати особливу роль у патофізіології артеріальної гіпертензії, яка залежить від об’єму. В дослідженні [39] показано, що УПФ збільшує вивільнення базального і вазопресин-стимульованого внутрішньоклітинного Са2+ у гладком'язових клітинах судин щурів у культурі та в тромбоцитах людини аналогічно нововідкритому ендотеліну. 
У плазмі крові та сечі натрійуретичну активність було продемонстровано за допомогою біоаналізу. Ця активність може змінюватися зі зміною натрієвого балансу організму.

ANP i BNP i їхній фермент деградації неприлізин стали клінічно важливими біомаркерами та/або терапевтичними мішенями для серцево-судинних захворювань [7]. Нещодавно був схвалений комбінований препарат, що складається з інгібітора неприлізина (сакубітрил) і інгібітора рецепторів ангіотензину II (валсартан) для пацієнтів із серцевою недостатністю. У клінічних дослідженнях були продемонстровані позитивні ефекти - зниження серцево-судинної смертності, скорочення термінів госпіталізації та смертності від усіх причин, більш виражені, ніж при використанні інгібіторів ангіотензин-перетворювального ферменту поодинці [41].

Гормони серця як аутокринні або паракринні фактори. Кардіоміоцити, фібробласти і ендотеліальні клітини можуть секретувати велику кількість факторів у різних формах - від білків, ліпідів і невеликих молекул до екзосом. На додаток до GDF-15 - міостатин і ANP/BNP, тільки деякі з цих факторів поступають у системну циркуляцію. Навпаки, багато з тих факторів, що секретуються клітинами серця, потрапляють локально в позаклітинний простір, не виходячи до системного кровотоку. Функції гормонів серця підсумовані в табл. 1 за [72], а обговорення фокусується на тих із них, що мають істотну клінічну значимість.

CNP - натрій-уретичний пептид C-типу широко експресується та не є специфічним для серця (оскільки ідентифікований не тільки в кардіоміоцитах, а й у нейронах головного мозку, а також у клітинах ендотелію) [19, 22]. Проте серцевий синтез CNP істотно підвищений у пацієнтів із хронічною серцевою недостатністю [56], а його регуляція серцевої функції здійснюється через специфічний рецептор (NPR-B) у серці [23].

Таблиця 1

\section{Гормони серця (зокрема аутокринні та паракринні фактори)}

\begin{tabular}{|c|c|c|c|}
\hline Гормони серця & Патофізіологічна роль & Клінічна значимість & Посилання \\
\hline ANP & Натрійурез і розширення судин & Серцева недостатність & {$[6]$} \\
\hline BNP & Натрійурез і розширення судин & $\begin{array}{l}\text { Серцева недостатність, біомар- } \\
\text { кери }\end{array}$ & [7] \\
\hline GDF-15 & $\begin{array}{l}\text { Інгібування патологічних проце- } \\
\text { сів в організмі }\end{array}$ & $\begin{array}{l}\text { Серцева недостатність, біомар- } \\
\text { кер для гострого коронарного } \\
\text { синдрому }\end{array}$ & [71] \\
\hline \multicolumn{4}{|l|}{ Міостатин } \\
\hline$(\mathrm{GDF}-8)$ & $\begin{array}{l}\text { Зменшення маси скелетних } \\
\text { м’язів }\end{array}$ & $\begin{array}{l}\text { Серцева кахексія, інфаркт мі- } \\
\text { окарда, гострий коронарний } \\
\text { синдром }\end{array}$ & [48] \\
\hline \multicolumn{4}{|c|}{ Гормони серця з аутокринною та паракринною дією } \\
\hline Активін А & Захист кардіоміоцитів & Інфаркт міокарда & [3] \\
\hline CNP & Вазодилатація & Серцева гіпертрофія & [9] \\
\hline CTRP9 & Кардіопротекція & Серцева недостатність & [72] \\
\hline ET-1 & $\begin{array}{l}\text { Сприяння виживанню кардіомі- } \\
\text { оцитів }\end{array}$ & $\begin{array}{l}\text { Серцева гіпертрофія, інфаркт } \\
\text { міокарда }\end{array}$ & [21] \\
\hline FGF-2 & Інгібування надмірної аутофагії & Серцева недостатність & [25] \\
\hline FGF-9 & Збереження систолічної функції & Інфаркт міокарда & [16] \\
\hline FGF-16 & $\begin{array}{l}\text { Профілактика серцевої гіпертро- } \\
\text { фії і фіброзу }\end{array}$ & Інфаркт міокарда & {$[5]$} \\
\hline FGF-21 & $\begin{array}{l}\text { Регуляція енергетичного мета- } \\
\text { болізму серця }\end{array}$ & Серцева гіпертрофія & [54] \\
\hline
\end{tabular}


Продовж. табл. 1

\begin{tabular}{|l|l|l|c|}
\hline FGF-23 & $\begin{array}{l}\text { Стимулювання фіброзу і діасто- } \\
\text { лічної дисфункції }\end{array}$ & $\begin{array}{l}\text { Серцева гіпертрофія, інфаркт } \\
\text { міокарда }\end{array}$ & [64] \\
\hline FSTL3 & $\begin{array}{l}\text { Активін-А-залежна міокардіо- } \\
\text { протекція }\end{array}$ & $\begin{array}{l}\text { Серцева гіпертрофія, інфаркт } \\
\text { міокарда }\end{array}$ & [8] \\
\hline IL-33/sST2 & $\begin{array}{l}\text { Антигіпертрофічний та антиві- } \\
\text { русний захист }\end{array}$ & $\begin{array}{l}\text { Iнфаркт міокарда, серцева гі- } \\
\text { пертрофія, sST2 є біомаркером } \\
\text { серцевої недостатності }\end{array}$ & [47] \\
\hline MANF & Кардіопротекція & Серцева гіпертрофія & [44] \\
\hline miRNA-1 & Посттранскрипційна регуляція & Гострий інфаркт міокарда & {$[12]$} \\
\hline PI16 & Інгібування гіпертрофії міокарда & Серцева гіпертрофія & {$[26]$} \\
\hline sFRP2 & Антагоніст Wnt сигналізації & Інфаркт міокарда & [57] \\
\hline sFRP3 & Антагоніст Wnt сигналінгу & Серцева недостатність & [58] \\
\hline
\end{tabular}

Примітки: CNP - натрійуретичний пептид С-типу; ЕT-1 - ендотелін-1; CTRP9 - C1q білок, пов'язаний із фактором некрозу пухлини-9; FGF - фактор росту фібробластів; FSTL1 - аналог фолістатину 1; MANF- мезенцефальний астроцитарний нейротрофічний фактор (білок стрес-реакції, що секретується кардіоміоцитами); miRNA — мікроPHK; PI16 - протеазний інгібітор 16; SFRP 2/3 — frizzled-споріднені білки, що секретуються

Кардіоспецифічна надекспресія CNP у щурів не впливає на розмір інфаркту міокарда при ішемічному/реперфузійному пошкодженні, але запобігає подальшої гіпертрофії [9]. Системна інфузія CNP істотно зменшує гіпертрофію та фіброз після інфаркту міокарда у тварин [18].

Члени білкового сімейства фолістатинів пов'язують і нейтралізують фактори сімейства TGF- $\beta$. Серцевий синтез фолістатин-подібних білків (FSTL1 і FSTL3) підвищено при серцевій недостатності у людини і в модельній системі у щурів з гіпертрофічною кардіоміопатією, індукованою навантаженням тиском [18]. Рівень FSTL1 у сироватці крові підвищений у пацієнтів із серцевою недостатністю і гострим коронарним синдромом [14]; отже, на думку авторів, він $\epsilon$ потенційним біомаркером серцево-судинних захворювань. Встановлено, що FSTL1 зменшує розмір інфаркту міокарда в моделях ішемії/реперфузійного пошкодження за рахунок пригнічення прозапальної сигналізації білка ВМР4 сімейства TGF- $\beta$. До того ж надекспресія FSTL1 у мишачих кардіоміоцитах викликає стійкість до гіпертрофії, викликаної перевантаженням тиском. Специфічна для кардіоміоцитів втрата FSTL1 посилює серцеву гіпертрофію і серцеву дисфункцію, не змінюючи при цьому вихідного фенотипу [51]. На відміну від позитивної ролі FSTL1, FSTL3 пов'язує активін-А і протидіє його серцевій захисній функції. У результаті специфічна для серця втрата FSTL3 послаблює ішемічне/реперфузійне пошкодження та прогресування гіпертрофії $[3,8]$.

FGFS - фактори росту фібробластів, разом із власними рецепторами виявлені в різних типах клітин серця і впливають на функцію серця аутокринним чи паракринним шляхом у людини та тварин [56]. Серед них високий рівень сироваткового FGF-21 встановлений при гострому інфаркті міокарда, ішемічній хворобі серця, серцевій недостатності та діабетичній кардіоміопатії [59]; отже FGF-21 є потенційним біомаркером серцево-судинних захворювань. FGF-21 також відіграє важливу роль у метаболізмі серця через аутокринні та/або паракринні механізми [5]. Крім серцево-судинної системи, FGF-21 регулює метаболічну сигналізацію в інших тканинах (жировій і мозковій) [38]. Аналог FGF-21 (LY2405319) нормалізує дисліпідемію та масу тіла у хворих із ожирінням і цукровим діабетом 2-го типу [63].

Як відомо, синтез і секреція серцевого інтерлейкіну-33 (IL-33) індукуються здебільшого в серцевих фібробластах біомеханічними стимулами, і він активує свій рецептор ST2 (suppression of tumorigenecity 2), що експресується кардіоміоцитами паракринним шляхом. ST2 є членом сімейства рецепторів IL-1 (IL-1R) і має дві первинні ізоформи (трансмембранна ізоформа - ST2L і розчинна ізоформа - SST2, яка експресується також кардіоміоцитами). Підвищення рівня ST2 може впливати на патологію міокарда. 
Використовуючи технологію структурної біоінформатики, дослідники [36] виявили нову послідовність, пов'язану з К-1, із бібліотеки ДНК. Цей білок отримав назву IL-33 і виявився функціональним лігандом ST2L, здатним активувати NF-kB. Це відкриття IL-33 як ліганда для ST2 дозволило визначити роль IL-33/ST2-сигналізації в міокарді. Результати дослідження показали, що сигналізація IL-33/ST2 відіграє ключову роль у регуляції реакції міокарда на біомеханічне перевантаження в серцевих фибробластах і кардіоміоцитах, оскільки обидва типа клітин є високоінтерактивними [42]. Скасування сигналізації ST2 у мишей призводило до вираженої серцевої гіпертрофії і фіброзу після перевантаження тиском; до того ж лікування очищеним рекомбінантним IL-33 захищало міокард. Ці дані дозволяють розглядати сигналізацію IL-33/ST2 як найважливіший кардіопротекторний механізм і формують уявлення про паракринну сигналізацію між кардиомиоцитами і серцевими фібробластами під час механічного перевантаження.

MiкроРHK (miRNA) - некодуючі PHK, що в складі від 18 до 25 нуклеотидів беруть участь у посттранскрипційній регуляції і продукуються клітинами серця, можуть бути вміщені в екзосомах, мікровезикулах та забезпечити опосередковано міжклітинну комунікацію в серці аутокринним або паракринним засобом. Окремі мікроРНК серцевого походження, що існують переважно в екзосомах, в істотній кількості знаходяться в сироватці крові пацієнтів із захворюваннями серця. $€$ дані, що miRNA-449 або miRNA-30а позиціонують підвищені рівні в крові у модельних системах і у пацієнтів із гострим інфарктом міокарда, що підтверджує їхній потенціал як біомаркерів при серцево-судинних захворюваннях [12].

Нещодавно транскриптомний аналіз (snRNAseq) одиничних клітин показав, що тільки частина кардіоміоцитів, фібробластів, ендотеліоцитів і інших клітин серця синтезують гормони серцевого походження [61]. Це порушує кілька фундаментальних питань у проблемі гормонів серця: чи існують певні популяції клітин серця, в яких з'являються значні здібності до синтезу і секреції гормонів? Якщо так, то які існують внутрішні генетичні компоненти та зовнішні сигнали, що управляють їхньою гормоновидільною функцією? Ймовірно, методи одноклітинної мультиоміки, що швидко розвиваються $[11,60]$, сприятимуть розвитку цієї сфери. Аналіз одноклітинного транскриптома дозволить ідентифікувати клітини серця, що продемонструють підвищену експресію гормонів, ферментів (наприклад, білків PSKS), а також механізми секреції ендоплазматичним ретикулумом, апаратом Гольджі тощо. Надалі, на тлі використання різних стимулів, аналіз одноклітинного епігеному дозволить додатково уточнити регуляторні механізми та позаклітинні сигнали, що впливають на функціонування клітин-гормонопродуцентів.

Отже, важливо підкреслити, що незалежно від основного місця продукції серцевих гормонів (серце, інші органи), згадані вище поліпептидні гормони функціонують синергетично, спільно сприяють регуляції серцево-судинної гемодинаміки, впливаючи на судинний тонус, діяльність вегетативної нервової системи та серцеву масу в нормі й при патології.

Висновки. 1. Обгрунтування парадигми «ендокринного серця» забезпечило перехід від класичного уявлення про серце як органу, функціонуючого виключно як кров'яний насос, до серця як саморегулюючої системи щодо навантаження в гуморальному плані.

2. Вивчення гормонів серцевого походження дозволило виявити їхні загальні функціональні особливості та підкреслити наявність гормонозалежного механізму, що серце використовує для зв'язку з іншими органами-мішенями, що контролюють серцево-судинну функцію. 


\section{Література.}

1. Алексеенко Л. П. Новое в проблеме сердечно-сосудистой регуляции: эндокринная функция сердца (обзор) / Л. П. Алексеенко, В. Н. Орехович // Вопросы медицинской химии. —-1987. - Т. 33, № 3. — С. 2-5.

2. Сытый В. П. Гормональная функция сердца в норме и при патологических состояниях // В. П. Сытый, А. Г. Мрочек // Медицинские новости. - 1995. — № 4. — С. 10-21.

3. Activin A and follistatin-like 3 determine the susceptibility of heart to ischemic injury / Y. Oshima, N. Ouchi, M. Shimano [et al.] // Circulation. — 2009. — Vol. 120, No 16. - P. 1606-1615.

4. Anderson S. B. Identification of a novel pool of extracellular pro-myostatin in skeletal muscle // S. B. Anderson, A. L. Goldberg, M. Whitman // J. Biol. Chem. - 2008. — Vol. 2836 No 11. — P. 7027-7035.

5. Angiotensin II-induced cardiac hypertrophy and fibrosis are promoted in mice lacking Fgf-16 / E. Matsumoto, S. Sasli, H. Kikotifa [et al.] // Genes Cells. — 2013. — Vol. 18, No 7. - P. 544-553.

6. Angiotensin-neprilysin inhibition versus enalapril in heart failure / J. J. McMurray, M. Packer, A. S. Desai [et al.] // N. Engl. J. Med. — 2014. — Vol. 371, No 11. — P. 993-1004.

7. Cao Z. BNP and NT-proBNP as diagnostic biomarkers for cardiac dysfunction in both clinical and forensic medicine / Z. Cao, Y. Jia, B. Zhu // Int. J. Mol. Sci. 2019. - Vol. 20, No 8. - P. 1820.

8. Cardiac myocyte-specific ablation of follistatin-like 3 attenuates stress-induced myocardial hypertrophy / M. Shimano, N. Ouchi, K, Nakamura [et al.] // J. Biol. Chem. - 2011. — Vol. 286, No 11. — P. 9840-9848.

9. Cardiomyocyte-restricted over-expression of C-type natriuretic peptide prevents cardiac hypertrophy induced by myocardial infarction in mice / Y. Wang, M. C. de Waard, A. Stremer-Kook [et al.] // Eur. J. Heart Fail. 2007. — Vol. 9, No. 6-7. — P. 548-557.

10. Castillero E. Cardiac myostatin upregulation occurs immediately after myocardial ischemia and is involved in skeletal muscle activation of atrophy / E. Castillero, H. Akashi, C. Wang // Biochem. Biophys. Res. Commun. - 2015. - Vol. 457, No 1. - P. 106-111.

11. Chen S. High-throughput sequencing of the transcriptome and chromatin accessibility in the same cell / S. Chen, B. B. Lake, K. Zhang // Nature Biotechnology. — 2019. — Vol. 37, No 12. — Vol. 1452-1457.

12. Circulating myocardial microRNAs from infarcted hearts are carried in exomes and mobiles bone marrow progenitor cells / M. Cheng, J. Yang, X. Zhao [et al.] // Nat. Commun. - 2019. - Vol. 10. - P. 959.

13. Circulation concentrations of CDF15 is apparently healthy elder by individuals and patients with chronic heart failure as assessed by a new immune radiometric sandwich assay / T. Kempf, R. Horn-Wiechmann, G. Brabant [et al.] // Clin. Chem. — 2007. — Vol. 53, No 2. - P. 284-291.
14. Circulatory concentrations of follistatin-like 1 in healthy individuals and patients with acute coronary syndrome as assessed by luminometric sandwich assay / C. Widera, R. Hoza-Wichmann, T. Kemp [et al.] // Clin. Chem. 2009. — Vol. 55, No 10. — P. 1794-1800.

15. Cloning and sequence analysis of DNA encoding a precursor for human atrial natriuretic polypeptide / S. Oikawa, M. Imai, A. Ueno [et al.] // Nature. — 1984. — Vol. 309, No 5970. — P. 724-726.

16. Conditional transgenic expression of fibroblast growth factor 9 in the adult mouse heart reduces heart failure mortality after myocardial infarction / M. Korf-Klingebiel, T. Kempf, K. D. Schlüter [et al.] // Circulation. - 2011. — Vol. 123, No 5. - P. 504-514.

17. CTRP9 knockout exaggerates lipotoxity in cardiac myocytes and high-fat diet-induced cardiac hypertrophy through inhibition the LKB1/AMAPK pathway / A. Zno, J. Zhao, T. Li [et al.] // J. Cell Mol. Med. — 2020. — Vol. 24, No 4. - P. 2635-2647.

18. C-type natriuretic peptide, a novel antifibrotic and antyhypertrophic agent, prevents cardiac remodeling after myocardial infarction / T. Soeki, I. Kishimoto, H. Okumura [et al.] // J. Ank. Cell. Cardiol. — 2005. — Vol. 45, No 4. - P. 608-616.

19. C-type natriuretic peptide (CNP): a new member of natriuretic peptide family identified in porcine brain / T. Sudoch, N. Minamino, K. Kangawa, H. Matsuo // Biochem. Biophys. Res. Commun. - 1990. — Vol. 168, No 2. - P. 863-870.

20. Differential regional expression of three natriuretic peptide receptor genes within primate tissues / J. N. Wilcox, A. Augustine, D. V. Goeadel, D. G. Lowe // Mol. Cell Biol. — 1991. — Vol. 11, No 7. — P. 3454-3462.

21. Endogenous endothelin-1 is required for cardiomyocyte survival in vivo / J. S. Zhao, W. Pan, R. Bekeredjian, R. V. Shohet // Circulation. — 2006. - Vol. 114, No 8. - P. 830-837.

22. Endothelial production of C-type natriuretic peptide and its marked augmentation by transforming growth factor-beta / S. Suga, K. Nakao, H. Itol [et al.] // J. Clin. Invest. — 1992. — Vol. 90, No 3. — P. 1145-1149.

23. Expression of C-type natriuretic peptide and its receptor NPR-B in cardiomyocytes / S. Del Ry, M. Cabiati, F. Vozzi [et al.] // Peptides. — 2011. — Vol. 32, No 8. — P. 1713-1718.

24. Expression of follistatin related genesis altered in heart failure / E. Lara-Pezzi, L. E. Felkin, E. J. Birks [et al.] // Endocrinology. - 2008. — Vol. 149. - P. 5822-5827.

25. Fibroblast growth factors is an essential cardioprotector factor in a closed-chest model of cardiac ischemia reperfusion injury / S. L. Honse, J. Wang, A. M. Gastro [et al.] // Physiology Rep. — 2015. — Vol. 3, No 1. - P. 12278.

26. Frost R. J. A secretion trap screen in yeast identifies protease inhibitor 16 as a novel antihypertrophic protein secreted from the heart / R. J. Frost, S. A. Engelhard 
// A secretion trap screen in yeast identifies protease inhibitor 16 as a novel antihypertrophic protein secreted from the heart // Circulation. — 2007. — Vol. 116. — P. 1768-1775.

27. GDF15 is a heart-derived hormone that regulates body growth / T. Wang, J. Lin, C. McDonald [et al.] // EMBO Mol. Med. — 2017. — Vol. 9, No 8. — P. 1150-1164.

28. GDF15 is an inflammation-induced central mediator of tissue tolerance / H. H. Luan, A. Wang, B. K. Hillard [et al.] // Cell. — 2019. — Vol. 178, No 5. - P. 1231-1244.

29. GDF15/MIC-1 functions as a protective and antihypertrophic factor released from the myocardium in association with SMAD protein activation / J. Xu, T. R. Kimball, J. N. Lorenz [et al.] // Circ. Res. — 2006. — Vol. 98, No 3. - P. 342-350.

30. GDF15 provides an endocrine signal of nutritional stress in mice and humans / S. Patel, A. Alvarez-Guaita, A. Melvin [et al.] // Cell Metab. — 2019. — Vol. 29, No 3. - P. 707-718.

31. Genetic studies of body mass index yield new insights for obesity biology / A. E. Locke, B. Kahali, S. T. Berndt [et al.] // Nature. — 2015. — Vol. 518, No 7538. — P. 197-206.

32. GFRAL is the center for GDF15 and is required for the anti-obesity effects of the ligand / L. Yang, C. C. Chand, Z. Sun [et al.] // Nat. Med. — 2017. — Vol. 23, No 10. - P. 1158-1166.

33. GFRAL is the receptor for CDF 15 and the ligand promotes weight loss in mice and nonhuman primates / S. E. Millican, X. Lin-Schmidt, C. N. Chin [et al.] // Nat. Med. - 2017. — Vol. 23, No 10. — P. 11501157.

34. Growth differentiation factor 15 maturation requires proteolytic cleavage by PCSK3, -5 , and -6 / J. J. Li, J. Liu, K. Lupino [et al.] // Mol. Cell Biol. — 2018. — Vol. 38, No 21. - P. e00249-18.

35. HGD polymorphism in macrophage-inhibitory cytokine1gene associated with prostate cancer / F. Lindmark, S. L. Zheng, F. Wiklund [et al.] // S. Natl. Cancer Inst. 2004. - Vol. 96, No 16. - P. 1248-1254.

36. Il-33, an interleukin-1-like cytokine that signals via the IL-1 receptor — related protein ST2 and induces T helper type 2-associated cytokine / J. Schmitz, A. Owyang, F. Oldhman [et al.] // Immunity. — 2005. — Vol. 23, No 5. - P. 479-490.

37. Kaufmann W., Wambach G. (Eds.) Endocrinology of the heart (1st ed.). — N-Y. : Springer, 2012. — 303 p.

38. Kliewer S. A. A dozen years of discovery: insights into the physiology and pharmacology of FGF21 / S. A. Kliewer, D. J. Mangelsdorf // Cell Metab. — 2019. — Vol. 29, No 2. - P. 246-253.

39. Kramer H. J., Meyer-Lehnert H., Predel H. G. Natriuretic hormones: endogenous Na-K-ATPase inhibitor(s) and atrial natriuretic peptide / W. Kaufmann, G. Wambach (eds) / Endocrinology of the heart. — Berlin, Heidelberg: Springer, 1989.
40. Lee S. J. Regulation of myostatin activity and muscle growth / S. J. Lee, A. C. McPherron // Proc. Natl. Acad. Sci. USA. - 2001. — Vol. 98, No 16. - P. 9306-9311.

41. Left ventricular hypertrophy in human essential hypertension / N. M. Wolfman, A. C. McPherron, W. N. Pappano[et al.] // Clin. Sci. — 2009. — Vol. 118 (2). - P. 137-145.

42. Manabe I. Gene expression in fibroblast and fibrosis: involvement in cardiac hypertrophy / I. Manabe, T. Shindo, R. Nagai // Circ. Res. - 2002. — Vol. 91, No 12. - P. 1103-1113.

43. McPherzan A. C. Regulation of skeletal muscle mass in mice by a new TGF-beta superfamily member / A. C. McPherzan, A. M. Lawler, S. J. Lee // Nature. — 1997. — Vol. 387, No 6628. — P. 83-90.

44. Mesencephalic astrocyte-derived neurotrophic factor is an ischemia-inducible secreted endoplasmic reticulum stress response protein in the heart / A. Tadimalla, P. J. Belmont, D. J. Thuerauf [et al.] // Circ. Res. — 2008. Vol. 103, No 11. — P. 1249-1258.

45. Mullin placenta and appetite genes GDF15 and IGFBP7 are associated with hyperemesis gravidarum / M. S. Fejzo, O. V. Sazonova, J. F. Sathirapongsasuti [et al.] // Nat. Commun. - 2018. - Vol. 9, No 1. — P. 1178.

46. Muscle wasting and cachexia in heart failure: mechanisms and therapies / S. von Haehling, N. Ebner, M. dos Santos [et al.] // Nat. Rev. Cardiol. — 2017. — Vol. 14, No 6. - P. 323-341.

47. Myocardial pressure overload induces systemic inflammation through endothelial cell IL-33 / W.-Y. Chen, J. Hong, J. Cannon [et al.] // Proc. Natl. Acad. Acad. Sci. USA. - 2015. - Vol. 112, No 23. - P. 7249-7254.

48. Myostatin activation in patients with advanced heart failure an after mechanical unloading / I. George, L. T. Bish, G. Kamalakkannan [et al.] // Eng. J. Heart. Fail. — 2010. — Vol. 12, No 5. - P. 444-453.

49. Myostatin, a transforming growth factor-beta superfamily members, is expressed in heart muscle and is unregulated in cardiomyocytes after infarct / M. Scharma, R. Kambadur, K. G. Mattheus [et al.] // J. Cell Physiol. 1999. — Vol. 180, No 1. - P. 1-9.

50. Non-homeostatic body weight regulation through a brainstem-restricted receptor for GDF15 / J. Y. Hsu, S. Crawley, M. Chen [et al.] // Nature. — 2017. — Vol. 550, No 7675. - P. 225-259.

51. Ogawa T. The heart as an endocrine organ / T. Ogawa, A. J. De Bold // Endocr. Connect. - 2014. — Vol. 3, No 2. - P. R31-R44.

52. Owens A. T. Neprilysin inhibitors: emerging therapy for heart failure / A. T. Owens, S. Brozena, M. Jessup // Annu. Rev. Med. - 2017. — Vol. 68. — P. 41-49.

53. PCSK6-mediated corin activation is essential for normal blood pressure / S. Chen, P. Cao, N. Dong [et al.] // Nat. Med. - 2015. — Vol. 21, No 9. — P. 1048-1053. 
54. Planavila A. FGF21 and cardiac physiopathology / A. Planavila, I. Redondo-Angulo, F. Villarroya // Front. Endocrinol (Lausanne). - 2015. - Vol. 6. - P. 133.

55. Potter L. R. Natriuretic peptides, their receptors and cyclic guanosine monophosphate-dependent signality functions / L. R. Potter, S. Abbey-Hoach, D. M. Dickey // Endocr. Rew. - 2006. - Vol. 27, No 1. - P. 42-47.

56. Schisler J. C., Land C. H., Willis M. (Eds.). Endocrinology of the heart in health and disease: integrated, cellular and molecular endocrinology of the heart (1st Ed). - N-Y: Academic Press, 2016. - 378 p.

57. Secreted frizzled-related protein 2 as a target in antibiotic therapeutic intervention / M. Mastri, Z. Shah, K. Hsieh [et al.] // Am. J. Physiol. Cell Physiol. — 2014. — Vol. 306, No 6. - P. 531-539.

58. Secreted frizzled-related protein 3 (eFRP3) in acute coronary symptoms / T. Ueland, K. Caidahl, E. T. Askevold [et al.] // Int. J. Cardiol. — 2015. — 190. — P. 217-219.

59. Serum FGF21 associated with future cardiovascular events in patients with coronary artery disease / X. Shen, X. Zhang, Y. Xu [et al.] // Cardiology. — 2018. — Vol. 139. - P. 212-218.

60. Single-cell multiomic analysis identifies regulatory programs in mixed-phenotype acute leukemia / J. M. Granja, S. Klemm, L. M. McGinnis [et al.] // Nat. Biotechnol. — 2019. — Vol. 37, No 12. — P. 1458-1465.

61. Single nucleus transcriptomic survey of the call diversity and functional maturation in postural mammalian hearts / P. Hu, J. Lin, J. Zhao [et al.] // Cienes. Develop. 2018. — Vol. 32, No 19-20. — P. 1344-1357.

62. Successive action of meprin A and neprilysin catabolizes B-type natriuretic peptide / K. Pankow, Y. Wang, F. Gembardt [et al.] // Circ. Res. — 2007. — Vol. 101, No 9. - P. 875-882.

63. The effects of LY2405319, an FGF21 analog, in obese human subjects with type 2 diabetes / G. Gaich, J. Y. Chien, H. Fu [et al.] // Cell Metab. — 2013. — Vol. 18, No 3. - P. 333-340.

64. The failing heart is a major source of circulating FGF23 via oncostatin $\mathrm{M}$ receptor activation / M. Richter, H. J. Lautze, T. Walther [et al.] // J. Heart Lung Transplant. - 2015. - Vol. 4, No 9. -P. 1211-1214.

65. The haplotype of the growth-differentiation factor 15 gene is associated with left ventricular hypertrophy in human essential hypertension / X. Wang, X. Yang, K. Sun [et al.] // Clin Sci (Lond). — 2009. — Vol. 118, No 2. - P. 137-145.

66. The metabolic effects of GDF15 are mediated by the orphan receptor GFRAL / P. J. Emmerson, F. Wang, Y. Du [et al.] // Nat Med. — 2017. — Vol. 23, No 10. — P. 1215-1219.

67. The MIC-1/GDF15-GFRAL pathway in energy homeostasis: implications for obesity, cachexia and other associated diseases / V. W. W. Tsai, Y. Husani, A.
Sainsbury [et al.] // Cell Metlab. — 2018. — Vol. 28, No 3. - P. 353-268.

68. The natriuretic peptide clearance locally modulates the physiological effects of the natriuretic peptide systems / W. Mastukawa, N. J. Gressic, N. Takahashi [et al.] // Proc. Nat. Acid. Sci. USA — 1999. — Vol. 96, No 13. - P. 7403-7408.

69. The propeptide of macrophage inhibitory cytokine (MIC-1), a TGF-beta superfamily member, acts as a quality control determinant for correctly folded MIC-1 / A. R. Bauskin, H. P. Zhang, W. D. Fairlie [et al.] // EMBO J. — 2000. — Vol. 19, No 10. — P. 2212-2220.

70. The TCT-beta superfamily cytokine MIC-1/CDF15: secretory mechanisms facilitate creation of latent stromal stores / A. R. Banskin, L. Jiang, X. W. Luo [et al.] // J. Interferon Cytokine. - 2010. — Vol. 30, No 1. - P. 389-397.

71. Wadlert K. C. Growth differentiation factor 15 as a biomarker in cardiovascular disease / K. C. Wadlert, F. T. Kemp, L. Wallentin // Clin. Chem. — 2017. — Vol. 63, No 1. - P. 140-151.

72. Zhao J. S. Cardiac endocrinology heart-derived hormones in physiology and disease / J. S. Zhao, L. Pei // JACC: Basic to translational scienceю - 2020. — Vol. 5, No 9. — P. 949-960.

\section{References.}

1. Alekseenko L. P., Orekhovich V. N. (1987). Novoe V probleme serdechno-sosudistoi regulyatsii: ehndokrinnaya funktsiya serdtsa (New in the problem of cardiovascular regulation: endocrine function of the heart (review)). Voprosy meditsinskoi khimii (Medical chemistry issues), 33 (3), 2-15. [In Russian].

2. Sytyi V. P., Mrochek A. G. (1995). Gormonal'naya funktsiya serdtsa $\mathrm{v}$ norme i pri patologicheskikh sostoyaniyakh (The hormonal function of the heart is normal and in pathological conditions). Meditsinskie novosti (Medical news), 4, 10-21. [In Russian].

3. Oshima Y., Ouchi N., Shimano M., Pimentel D. R., ...Walsh K. (2009). Activin A and follistatin-like 3 determine the susceptibility of heart to ischemic injury. Circulation, 120 (16), 1606-1615.

4. Anderson S. B., Goldberg A. L., Whitman M. (2008). Identification of a novel pool of extracellular promyostatin in skeletal muscle. J. Biol. Chem., 283 (11), 7027-7035. doi: 10.1074/jbc.M706678200.

5. Matsumoto E., Sasli S., Kikotifa H., ... Itoh N. (2013). Angiotensin II-induced cardiac hypertrophy and fibrosis are promoted in mice lacking Fgf-16. Genes Cells, 18 (7), 544-553. doi: 10.1111/gtc.12055.

6. McMurray J. J., Packer M., Desai A. S., Rizkala A. R. ... PARADIGM-HF Investigators and Committees (2014). Angiotensin-neprilysin inhibition versus enalapril in heart failure. N. Engl J. Med., 371 (11), 993-1004. doi: 10.1056/NEJMoa1409077. 
7. Cao Z., Jia Y., Zhu B. (2019). BNP and NT-proBNP as Diagnostic Biomarkers for Cardiac Dysfunction in both clinical and Forensic Medicine. Int. J. Mol. Sci., 20 (8), 1820. doi: 10.3390/ijms20081820.

8. Shimano M., Ouchi N., Nakamura K., ... Walsh K. (2011). Cardiac myocyte-specific ablation of follistatin-like 3 attenuates stress-induced myocardial hypertrophy. $J$. Biol. Chem., 286 (11), 9840-9848. doi: 10.1074/jbc. M110.197079.

9. Wang Y., de Waard M. C., Stremer-Kook A., ... Walther T. (2007). Cardiomyocyte-restricted overexpression of C-type natriuretic peptide prevents cardiac hypertrophy induced by myocardial infarction in mice. Eur. J. Heart Fail., 9 (6-7), 548-557. doi: 10.1016/j. ejheart.2007.02.006.

10. Castillero E., Akashi H., Wang C. (2015). Cardiac myostatin upregulation occurs immediately after myocardial ischemia and is involved in skeletal muscle activation of atrophy. Biochem. Biophys. Res. Commun., 457 (1), 106-111. doi: 10.1016/j.bbrc.2014.12.057.

11. Chen S., Lake B. B., Zhang K. (2019). High-throughput sequencing of the transcriptome and chromatin accessibility in the same cell. Nature Biotechnology, 37 (12), 1452-1457. doi: 10.1038/s41587-019-0290-0.

12. Cheng M., Yang J., Zhao X., ... Qin G. (2019). Circulating myocardial microRNAs from infarcted hearts are carried in exomes and mobiles bone marrow progenitor cells. Nat. Commun., 10 (1), 959. doi: 10.1038/s41467-019-08895-7.

13. Kempf T., Horn-Wiechmann R., Brabant G. ... Wollert K. C. (2007). Circulation concentrations of CDF15 is apparently healthy elder by individuals and patients with chronic heart failure as assessed by a new immune radiometric sandwich assay. Clin. Chem.. 53, 284-291. doi: 10.1373/clinchem.2006.076828.

14. Widera C., Hoza-Wichmann R., Kemp T. ... Wollert K. C. (2009). Circulatory concentrations of follistatin-like 1 in healthy individuals and patients with acute coronary syndrome as assessed by luminomefric sandwich assay. Clin. Chem., 55 (10), 1794-1800. doi: 10.1373/ clinchem.2009.129411.

15. Oikawa S., Imai M., Ueno A., ... Matsuo H. (1984). Cloning and sequence analysis of DNA encoding a precursor for human atrial natriuretic polypeptide. Nature, 309 (5970), 724-726. doi: 10.1038/309724a0.

16. Korf-Klingebiel M., Kempf T., Schlüter K. D., ... Wollert K. C. (2011). Conditional transgenic expression of fibroblast growth factor 9 in the adult mouse heart reduces heart failure mortality after myocardial infarction. Circulation, 123 (5), 504-514. doi: 10.1161/ CIRCULATIONAHA.110.989665.

17. Zno A., Zhao J., Li T., ... Guo Y. (2020). CTRP9 knockout exaggerates lipotoxity in cardiac myocytes and high-fat diet-induced cardiac hypertrophy through inhibition the LKB1/AMAPK pathway. J. Cell Mol. Med., 24 (4), 2635-2647. doi: 10.1111/jcmm.14982.
18. Soeki T., Kishimoto I., Okumura H., ... Kangawa K. (2005). C-type natriuretic peptide, a novel antibiotic and antyhipertrophyk agent, prevents cardiac remodeling after myocardial infarction. J. Ank. Cell. Cardiol., 45 (4), 608-616. doi: 10.1016/j.jacc.2004.10.067.

19. Sudoch T., Minamino N., Kangawa K., Matsuo H. (1990). C-type natriuretic peptide (CNP): a new member of natriuretic peptide family identified in porcine brain. Biochem. Biophys. Res. Commun., 168 (2), 863-870. doi.org/10.1016/0006-291X(90)92401-K.

20. Wilcox J. N., Augustine A., Goeadel D. V., Lowe D. G. (1991.). Differential regional expression of three natriuretic peptide receptor genes within primate tissues. Mol. Cell Biol., 11 (7), 3454-3462. doi: 10.1128/ mcb.11.7.3454.

21. Zhao J. S., Pan W., Bekeredjian R., Shohet R. V. (2006). Endogenous endothelin-1 is required for cardiomyocyte survival in vivo. Circulation, 114 (8), 830-837. doi: org/10.1161/CIRCULATIONAHA.105.577288.

22. Suga S., Nakao K., Itol H., ... Imura H. (1992). Endothelial production of C-type natriuretic peptide and its marked augmentation by transforming growth factor-beta. J. Clin. Invest., 90 (3), 1145-1149. doi: 10.1172/JCI115933.

23. Del Ry S., Cabiati M., Vozzi F., ... Mattii L. (2011). Expression of C-type natriuretic peptide and its receptor NPR-B in cardiomyocytes. Peptides, 32(8), 1713-1718. doi: 10.1016/j.peptides.2011.06.014.

24. Lara-Pezzi E., Felkin L. E., Birks E. J., ... Barton P. J. R. (2008). Expression of follistatin related genesis altered in heart failure. Endocrinology, 149 (11), 5822-5827. doi: 10.1210/en.2008-0151.

25. Honse S. L., Wang J., Gastro A. M., ... Ornitz D. M. (2015). Fibroblast growth factors is an essential cardioprotector factor in a closed-chest model of cardiac ischemia-reperfusion injury. Physiology Rep., 3(1), 12278. doi: 10.14814/phy2.12278.

26. Frost R. J., Engelhard S. A. (2007). A secretion trap screen in yeast identifies protease inhibitor 16 as a novel antihypertrophic protein secreted from the heart. Circulation, 116 (16), 1768-1775. doi: 10.1161/ CIRCULATIONAHA. 107.696468.

27. Wang T., Lin J., McDonald C., ... Pei L. (2017). GDF15 is a heart-derived hormone that regulates body growth. EMBO Mol. Med., 9 (8), 1150-1164. doi: 10.15252/ emmm.201707604.

28. Luan H. H., Wang A., Hillard B. K., ... Medzhitov R. (2019). GDF15 is an inflammation-induced central mediator of tissue tolerance. Cell, 178 (5), 1231-1244. doi: 10.1016/j.cell.2019.07.033.

29. Xu J., Kimball T. R., Lorenz J. N., ... Molkentin J. D. (2006). GDF15/MIC-1 functions as a protective and antihypertrophic factor released from the myocardium in association with SMAD protein activation. Circ. Res., 98 (3), 342-350. doi: 10.1161/01. RES.0000202804.84885.d0. 
30. Patel S., Alvarez-Guaita A., Melvin A., ... O’Rahilly S. (2019). GDF15 provides an endocrine signal of nutritional stress in mice and humans. Cell Metab., 29 (3), 707-718. doi: 10.1016/j.cmet.2018.12.016.

31. Locke A. E., Kahali B., Berndt S. T., ... Speliotes E. K. (2015). Genetic studies of body mass index yield new insights for obesity biology. Nature, 518 (7538), 197206. doi: 10.1038/nature14177.

32. Yang L., Chand C. C., Sun Z., ... Jorgensen S. B. (2017). GFRAL is the center for GDF15 and is required for the anti-obesity effects of the ligand. Nat. Med., 23 (10), 1158-1166. doi: 10.1038/nm.4394.

33. Millican S. E., Lin-Schmidt X., Chin C. N., ... Rangwala S. M. (2017). GFRAL is the receptor for CDF 15 and the ligand promotes weight loss in mice and nonhuman primates. Nat. Med., 23 (10), 1150-1157. doi: 10.1038/ nm.4392.

34. Li J. J., Liu J., Lupino K., ... Pei L. (2018). Growth differentiation factor 15 maturation requires proteolytic cleavage by PCSK3, -5, and -6. Mol. Cell Biol., 38 (21), 00249-18. doi: 10.1128/MCB.00249-18.

35. Lindmark F., Zheng S. L., Wiklund F., ... Xu J. (2004). HGD polymorphism in macrophyze-inhibitirs cytokine1 gene associated with prostate cancer. S. Netl. Cancer Inst., 96 (16), 1248-1254. doi: 10.1093/jnci/djh227.

36. Schmitz J., Owyang A., Oldhman F., ... Kastelein, R. A. (2005). Il-33, an interleukin-1-like cytokine that signals via the IL-1 receptor -related protein ST2 and induces T helper type 2-associated cytokine. Immunity, 23 (5), 479-490. doi: 10.1016/j.immuni.2005.09.015.

37. Kaufmann W., Wambach G. (Eds.) (2012). Endocrinology of the heart (1st ed.). N-Y: Springer.

38. Kliewer S. A., Mangelsdorf D. J. (2019). A dozen years of discovery: insights into the physiology and pharmacology of FGF21. Cell Metabolism, 29(2), 246253. doi.org/10.1016/j.cmet.2019.01.004.

39. Kramer H. J., Meyer-Lehnert H., Predel H. G. (1989). Natriuretic hormones: endogenous Na-KATPase inhibitor(s) and atrial natriuretic peptide. In: W. Kaufmann, G. Wambach. (Eds) Endocrinology of the heart. Berlin, Heidelberg: Springer. doi: org/10.1007/978-3-642-83858-3_9.

40. Lee S. J., McPherron A. C. (2001). Regulation of myostatin activity and muscle growth. Proc. Natl. Acad. Sci USA, 98 (16), 9306-9311. doi: 10.1073/ pnas.151270098.

41. Wolfman N. M., McPherron A. C., Pappano W. N., ... Laragh J. H. (2009). Left ventricular hypertrophy in human essential hypertension. Clin. Sci., 118 (2), 137145. doi: 10.1161/01.hyp.9.2_pt_2.ii53.

42. Manabe I., Shindo T., Nagai R. (2002). Gene expression in fibroblast and fibrosis: involvement in cardiac hypertrophy. Circ. Res., 91(12), 1103-1113. doi: 10.1161/01.res.0000046452.67724.b8.

43. McPherzan A. C., Lawler A. M., Lee S. J. (1997). Regulation of skeletal muscle mass in mice by a new
TGF-beta superfamily member. Nature, 387 (6628), 83-90. doi: 10.1038/387083a0.

44. Tadimalla A., Belmont P. J., Thuerauf D. J., ... Glembotski C. C. (2008). Mesencephalic astrocytederived neurotrophic factor is an ischemia-inducible secreted endoplasmic reticulum stress response protein in the heart. Circ. Res., 103 (11), 1249-1258. doi: 10.1161/CIRCRESAHA.108.180679.

45. Fejzo M. S., Sazonova O. V., Sathirapongsasuti J. F., ... Patrick M. (2018). Mullin placenta and appetite genes GDF15 and IGFBP7 are associated with hyperemesis gravidarum. Nat. Commun., 9 (1), 1178. doi: 10.1038/ s41467-018-03258-0.

46. Von Haehling S., Ebner N., dos Santos M., Springer J., Anker S. D. (2017). Muscle wasting and cachexia in heart failure: mechanisms and therapies. Nat. Rev. Cardiol., 14 (6), 323-341. doi: 10.1038/nrcardio.2017.51.

47. Chen W.-Y., Hong J., Cannon J., Kakkar R., Lee R. T. (2015). Myocardial pressure overload induces systemic inflammation through endothelial cell IL-33. Proc. Natl. Acad. Acad. Sci. USA, 112 (23), 7249-7254. doi: 10.1073/pnas.1424236112.

48. George I., Bish L. T., Kamalakkannan G., ... Maybaum S. (2010). Myostatin activation in patients with advanced heart failure an after mechanical unloading. Eng. J. Heart. Fail., 12 (5), 444-453. doi: 10.1093/eurjhf/ hfq039.

49. Scharma M., Kambadur R., Mattheus K. G., ... Bass J. J. (1999). Myostatin, a transforming growth factor-beta superfamily members, is expressed in heart muscle and is unregulated in cardiomyocytes after infarct. J. Cell Physiol., 180 (1), 1-9. doi: 10.1002/(SICI)1097-4652(199907)180:1<1::AIDJCP1>3.0.CO;2-V.

50. Hsu J. Y., Crawley S., Chen M., ... Allan B. B. (2017). Non-homeostatic body weight regulation through a brainstem-restricted receptor for GDF15. Nature, 550 (7675), 225-259. doi: 10.1038/nature24481.

51. Ogawa T., de Bold A. J. (2014). The heart as an endocrine organ. Endocr. Connect., 3(2), R31-R44. doi: 10.1530/EC-14-0012.

52. Owens A. T., Brozena S., Jessup M. (2017). Neprilysin inhibitors: emerging therapy for heart failure. Annu. Rev. Med., 68, 41-49. doi: 10.1146/annurevmed-052915-015509.

53. Chen S., Cao P., Dong N., ... Wu Q. (2015). PCSK6mediated corin activation is essential for normal blood pressure. Nat. Med., 21 (9), 1048-1053. doi: 10.1038/ nm.3920.

54. Planavila A., Redondo-Angulo I., Villarroya F. (2015). FGF21 and cardiac physiopathology. Front Endocrinol (Lausanne), 6, 133. doi: 10.3389/fendo.2015.00133.

55. Potter L. R., Abbey-Hoach S., Dickey D. M. (2006). Natriuretic peptides, their receptors and cyclic guanosine nonfhosphate - dependendent signality functions. Endoc. Rew., 27 (1), 42-47. doi: 10.1210/er.2005-0014. 
56. Schisler J. C., Land C. H., Willis M. (Eds.) (2016). Endocrinology of the heart in health and disease: integrated, cellular and molecular endocrinology of the heart (1st ed.). N-Y: Academic Press.

57. Mastri M., Shah Z., Hsieh K., ... Lee T. (2014). Secreted Frizzled-related protein 2 as a target in antibiotic therapeutic intervention. Am. J. Physiol. Cell Physiol., 306 (6), 531-539.

58. Ueland T., Caidahl K., Askevold E. T., ... Aukrust P. (2020). Secreted frizzled-related protein 3 (eFRP3) in acute coronary symptoms. Int. J. Cardiol., 190, 217-219. doi: 10.1016/j.ijcard.2015.03.401.

59. Shen X., Xhang X., Xu Y., ... Jia W. (2018). Serum FGF21 associated with future cardiovascular events in patients with coronary artery disease. Cardiology, 139, 212-218. doi.org/10.1159/000486127.

60. Granja J. M., Klemm S., McGinnis L. M., ... Greenleaf W. J. (2019). Single-cell multiomic analysis identifies regulatory programs in mixed-phenotype acute leukemia. Nat. Biotechnol., 37 (12), 1458-1465. doi: 10.1038/s41587-019-0332-7.

61. Hu P., Lin J., Zhao J., ... Pei L. (2018). Single nucleus transcriptomic survey of the call diversity and functional maturation in postural mammalian hearts. Genes Develop., 32 (19-20), 1344-1357 doi: 10.1101/ gad.316802.118.

62. Pankow K., Wang Y., Gembardt F., ... Walther T. (2007). Successive action of meprin A and neprilysin catabolizes B-type natriuretic peptide. Circ. Res., 101 (9), 875-882. doi: 10.1161/circresaha.107.153585.

63. Gaich G., Chien J. Y., Fu H., ... Moller D. E. (2013). The effects of LY2405319, an FGF21 analog, in obese human subjects with type 2 diabetes. Cell Metab. 18 (3), 333-340. doi: 10.1016/j.cmet.2013.08.005. PMID: 24011069.

64. Richter M., Lautze H. J., Walther T., Braun T., Kostin S., Kubin T. (2015). The failing heart is a major source of circulating FGF23 via oncostatin M receptor activation. J Heart Lung Transplant., 34 (9), 1211-1214. doi: 10.1016/j.healun.2015.06.007.
65. Wang X., Yang X., Sun K., ... Hui R. (2009). The haplotype of the growth-differentiation factor 15 gene is associated with left ventricular hypertrophy in human essential hypertension. Clin. Sci. (Lond.), 118 (2), 137145. doi: 10.1042/CS20080637.

66. Emmerson P. J., Wang F., Du Y., ... Wu X. (2017). The metabolic effects of GDF15 are mediated by the orphan receptor GFRAL. Nat. Med., 23 (10), 1215-1219. doi: 10.1038/nm.4393.

67. Tsai V. W. W., Husani Y., Sainsbury A., Brown D. A., Breit S. N. (2018). The MIC-1/GDF15-GFRAL pathway in energy homeostasis: implications for obesity, cachexia and other associated diseases. Cell Metab., 28 (3), 353-268. doi: 10.1016/j. cmet.2018.07.018.

68. Mastukawa W., Takahashi N., Pandey K. N., ... Smithies O. (1999). The natriuretic peptide clearance locally modulates the physiological effects of the natriuretic peptide systems. Proc. Nat. Acid. Sci. USA, 96 (13), 7403-7408. doi: 10.1073/ pnas.96.13.7403.

69. Bauskin A. R., Zhang H. P., Fairlie W. D., ... Breit S. N. (2000). The propeptide of macrophage inhibitory cytokine (MIC-1), a TGF-beta superfamily member, acts as a quality control determinant for correctly folded MIC-1. EMBO J. 19 (10):2212-20. doi: 10.1093/ emboj/19.10.2212.

70. Banskin A. R., Jiang L., Luo X. W., Wu L., Brown D. A., Breit S. N. (2010). The TNF-beta superfamily cytokine MIC-1/GDF15: secretory mechanisms facilitate creation of latent stromal stores. J. Interferon. Cytokine, 30 (1), 389-397. doi: 10.1089/jir.2009.0052.

71. Wadlert K. C., Kemp F. T., Wallentin L. (2017). Growth differentiation factor 15 as a biomarker in cardiovascular disease. Clin. Chem., 63 (1), 140-151. doi: 10.1373/ clinchem.2016.255174.

72. Zhao J. S., Pei L. (2020). Cardiac endocrinology heartderived hormones in physiology and disease. JACC: Basic to translational science, 5 (9), 949-960. doi. org/10.1016/j.jacbts.2020.05.007. 